\title{
Epic Anger, and the State of the (Roman) Soul in Virgil's First Simile
}

\author{
Kirk Freudenburg \\ Yale University
}

Virgil's Aeneid begins with the goddess, Juno, both 'still' and 'already' angry: mene incepto desistere victam? 'Am I to desist from what I've begun, beaten?' Rivers of Trojan blood have been spilt, and Priam's city has been looted and leveled. Extreme revenge has been exacted in the form of retaliatory rapes, forced enslavements, and so on. And yet somehow Juno thinks that her project of paying back the Trojans is not only not finished, but only just begun. The famous, translinguistic pun that issues from her first words (mene incepto) reminds us of Achilles' rage, certainly, but by the Iliad's end Achilles has gained some

\footnotetext{
This paper is a heuristic 'first go' at an idea that I have been mulling over for years, on the problem of anger in ancient epic, and the soul work of Virgil's first simile. Since I plan to do a larger workup of these ideas for a (distantly) forthcoming book, I will be more than happy to receive feedback on the paper's contents and arguments. The paper's core ideas were tested at the annual Latin Day Colloquium held at Yale University on April 16, 2016. For helpful comments and criticisms, I wish to thank the day's star and colloquium leader, Denis Feeney, as well as the event's invited speakers, Jay Reed, Tom Biggs, and Irene Peirano. Thanks also to Christina Kraus for organizing the event, and to the group of graduate respondents who were active participants throughout the day: Niek Janssen, Rachel Love, Kyle Conrau-Lewis, and Treasa Bell.
} 
perspective on his rage, and his revenge taking has (at least for the time being) played itself out. Reconciling himself to Priam, and to his own humanity, Achilles returns the body of Hector to his father, and he promises a twelve-day armistice that will allow the Trojans to bury their dead. In the divine council of Il. 24.33-76, Zeus tells Hera that she has no choice: she must relent. And that message is passed down to Achilles by Thetis. Both Hera and Achilles are forced to do what they are told, and yet it is clear that Achilles has been made to face up to the cost of his rage in ways that Juno has not. By the time the curtain rises on the Aeneid, she is still at it, hounding the last of the city's refugees outside the borders of her old Homeric world.

Virgil asks in line 11: tantaene animis caelestibus irae? 'Are the gods in heaven capable of such vehement wrath?'Put the way he puts it, the question suggests its own answer, because the term for 'heaven dwellers' (caelestibus) covertly names the goddess of Carthage, Tanit, whom Romans knew as dea Caelestis, Juno Caelestis, or simply Caelestis. Not all the gods in heaven, then, but that particular heaven dweller, is the one driven by such extreme rage. The idea is immediately taken up with in the next lines, where Virgil explains Juno's wrath in terms of her abiding concern for Carthage, a city as yet un-built: urbs antiqua fuit ... Karthago 'there was an ancient city ... Carthage.' In Punic the name Karthago, means 'the new city,' so we have yet another translational pun in these lines that can be heard to say 'there was an ancient city ... the new city.' ${ }^{2}$ There is irony here, of course, but also a crucial first hint that the old time horizons observed by Homer will no longer apply. Ancient to Virgil's audience, and long since wiped off the map, the 'ancient city' of Carthage will be spotted rising from the soil in Virgil's poem, as a 'new city' founded by Dido, even as the old new city, which

2 For the translinguistic figura etymologica in the phrase urbs antiqua, see Reed (2007,129-30). On the reference to the Carthaginian goddess Tanit/Caelestis in caelestibus, see Selden (2014, 230-1). 
had been leveled and salted more than 120 years before, was being newly rebuilt by Augustus in Virgil's own present (along with her sister city in Spain, Carthago Nova 'the new new city'). ${ }^{3}$

Juno's wrath is that of a tragic Medea: barbarized, feminized, and completely out of control. Like the anger that consumes Achilles, her anger is impressive for being so unbending, and capable of such vast destruction. And yet, despite resemblances that are obvious enough, Juno is remarkably unlike the gods and heroes from whom she is constructed: those characters never strayed across the strict ethnic, spatial, and temporal confines of the epics and tragedies that kept them hemmed in as characters. They were as lions howling from their cages. Not so, Juno. Made over as Tanit, an enemy of Rome's ever expanding world order, Juno storms across those old generic borders, into the realm of Clio, and the lived history of Rome. As such, her rage is scarier and more real and relatable than theirs, and it tends to smolder in the ashes of whatever pyre it has fueled, only to flare up again, (like a phoenix, or a Phoenician Carthage) from the ashes that Rome has made of it. Her reconciliations are notoriously many, and they never quite take. ${ }^{4}$ And that leaves Virgil with a teleology problem to deal with that Homer and Euripides never had to face. Somehow he must manage Juno's anger in a way that will allow Aeneas' imperial project to move forward, and the poem to end, but without putting an end to the anger by which the poem has been fueled. He must reconcile Juno for the time

3 On the collapsing timescales ('wormholes') of the Aeneid, see Feeney (2007, 161-3). On the rebuilding of Carthage during the reign of Augustus, see Thomas (2007, 145-6). On the potential slippage between old Carthage and new (Colonia Victrix Iulia Nova Carthago) in Virgil's Aeneid, see Shi and Morgan (2015). On the wholesale remaking of Spanish cities by Augustus and Agrippa in aftermath of the Cantabrian wars (29-19 BCE), see MacMullen (2000) 50-84.

4 The classic study of the 'Reconciliations of Juno' (emphasizing the plural) is Feeney (1984). 
being, in a way that keeps her anger on a slow boil, until such time as it is needed again as a source for renewed hatreds, and further wars. Put differently, Virgil needs to write his ending in a way that anticipates Ennius, and the freshly enraged Juno of the Annales. ${ }^{5}$ Already in antiquity, the question of how to put aside Juno's anger without resolving it was debated among scholars of the Aeneid. One of the ways that the question was solved can be made out from Servius's remarks on the heavenly concilium of Aeneid 12.793-842, where Jupiter and Juno reach a settlement that allows the poem to end. In commenting on these lines, Servius tells his readers that Juno was successfully placated (exorata) in the second punic war, but only later, in the final war against Carthage, was she 'translated' (translata) to Rome, along with her rites (in Ennius, Juno is hostile to Rome for much of the second Punic War, but ends up relenting and giving aid to the Roman cause ${ }^{6}$ ). Such comments speak to the long durée of Juno's anger, as well as to the necessary irresolution of the Aeneid's end. But there are several aspects of the endinitiating concilium, both as a deal brokered by Juno, and as an anger problem commented on by Servius, that deserve further study, because they have much to tell us about how thoroughly 'domesticated' Virgil's translation of Juno's anger is, both in its structuration (as a problem to be solved via negotiation) and in the peculiarly Roman qualities that inhere in its partial/ temporary placation. ${ }^{7}$

First, looking to the Homeric background of the heavenly negotiation that allows the Aeneid to end, in book 24 of the Iliad Zeus intervenes in the heated exchange that takes place between Apollo and Hera by ordering Hera to stop flying off in

\footnotetext{
On Virgil writing as if in anticipation of Ennius, see Feeney (1984, 181-2).

6 On the reconciliation of Juno to the cause of Rome in Ennius's Annales, see Skutsch (1985, 465-6).

7 On 'domesticating' translation in Roman appropriations of Greek literature, see Feeney $(2015,56-64)$.
} 


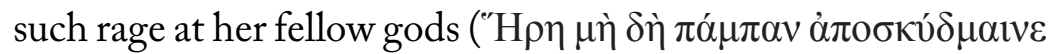
$\theta \varepsilon o i ̃ \sigma ı, ~ 65)$. He decrees that Achilles must accept a ransom for Hector's body and give it back to Priam. And that's that. Zeus lays down the law, and the other gods fall in line. Despite the lather of rage that she has worked herself into, Hera backs down and says not another word. In fact, she disappears from the poem altogether and is not heard from again. That is not the way Virgil stages his version of the end-initiating concilium of book 12 . He departs radically from the Homeric original by staging a back-and-forth negotiation between Jupiter and Juno that finds them settling into a compromise. He has introduced a drawn out process of negotiation that was not there before, overhauling the scene as a version of Roman cultural practice. ${ }^{8}$ Though it is never pointed out in the commentaries, the deal that is hashed out between Jupiter and Juno refers to the deals that were struck (the condiciones, the foedera) between Rome and her enemies (potential or actual) in order to avert, or conclude, hostilities, and to expand Rome's imperial reach into new territories. ${ }^{9}$ Jupiter deals with Juno the way Rome dealt with whatever part of the world came under her imperial boot. $\mathrm{He}$ says, 'look, coniunx, I am Jupiter,' as if to say, 'I am Rome.' 'I will have no more of this: ulterius temptare veto. Defying me is pointless because you know that, in the end, I will have my way. I do not lose. That means we can do this the hard way

8 I say 'overhauling' with reference to the spatial underpinning/tenor of Latin translatio.

9 On the elaborate array of individual (largely makeshift) agreements that Rome used to incorporate conquered cities and rivals into the Roman state, see Scullard (1969, 88-90; 126-32), and Sherwin-White (1973). On the minimal administrative machinery imposed on incorporated communities, and the Roman preference for keeping pre-existing political structures in place, see Lintott (1980), and Woolf (1998, 34-40; 65-7); cf. Sherwin-White (1973, 71), concerning the settlement of $338 \mathrm{BC}$ : 'When the evidence is considered as a whole ... the general indication is clearly that Rome did not seek to abolish the local life of her new boroughs ... in however rudimentary a fashion, Rome entered at this period on the road that led to the municipal system of the empire.' 
(lots of pointless violence, wasteful destruction, and disgrace just look to the crosses outside of any given town in my world, and to the dead zones that were once great cities, and you will see what I mean). Or we can do this the easy way, which is the preferred way, and the way that the gods would have it. In this scenario we do not destroy you, and there is no (or at least minimal) bloodshed. Rather, you concede to the inevitability of our success, and then you will be folded into that success as one of us. We mix and marry and have children together, and soon enough they will become citizens of Rome, and conquerors themselves. You keep your religion and your cultural habits, perhaps with some modifications, and we toss in some of ours. As to language, you'll speak your own, of course, and you can continue to wear your native dress. But the leaders among you will learn Latin (the language of the courts, assemblies, and so on) and they will wear the toga - an outfit that even we Romans don't like to wear. The important thing is that you become Romans, fighting for a new collective cause, enjoying the benefits of our shared success.' Such is the deal that Rome offers to the beaten, and it is from such deals that Virgil crafts the final pact between Jupiter and Juno.

For his part, Jupiter lets Juno do most of the demanding, and he puts his concession to her in words that remind us of her opening outburst: verum age et inceptum frustra summitte furorem: / do quod vis, et me victusque volensque remitto. 'But come now, scale back the fury that you've pointlessly undertaken. I give you what you want. Beaten, and of my own will, I relent.' Respecting her powers to defy him and cause further devastation, Jupiter concedes to her demands. He declares himself the loser, even as he has just won from Juno the crucial concession that allows Aeneas to defeat her beloved Turnus. There is little resemblance here to the concilium deorum of Iliad 24, because this is a negotiation made over from a very different Roman world, where noble women were possessed of very real powers, and where they were not to be trifled with or summarily ordered 
about. In fact Jupiter began the negotiation by trying to pull rank on Juno, as husband to wife: 'what's the end going to be, wife?' (quae iam finis erit, coniunx? 793). ${ }^{10}$ But by the time she is done with him, his tone is that of someone who has lost whatever upper hand he may have thought he had: 'es germana Iovis Saturnique altera proles / irarum tantos volvis sub pectore fluctus' ('you are Jupiter's sister from the same parent, and the second offspring of Saturn. So massive are the tides of wrath that you roll beneath your chest'). In the course of these negotiations, Juno has gone from 'wife' to 'sister,' and it is as his sister, an absolute equal in the quality of her birth (an altera inter pares), that Juno wins the dazzling concessions that allow her to relent, and the poem to end. ${ }^{11}$

Servius is not quite sure what to make of Jupiter's statement in line 130 'you are the Jove's sister from the same parent, and the second born of Saturn.' Why does Jupiter say that to Juno here? Servius indicates that some commentators construed this statement rather as I take it above, as Jupiter's acknowledgment of the impressive power that she wields in forcing him to cede to her demands. But Servius says that, taken this way, the line is not a good fit for the line that follows, where Jupiter continues by saying: 'so massive are the tides of wrath that you roll beneath your chest.' Servius thinks that it is in connection to this line that Jupiter mentions her birth, because he needs to explain not just the massiveness of her rage, but her superhuman ability to keep it in check, as if reserving it for a later time. Paraphrasing Jupiter's thought process, Servius writes: 'being from such stock

10 In contrast, Tarrant (2012) ad loc. takes the vocative coniunx as 'intimate' rather than exasperated in tone.

11 Cf. Apuleius Met. 6.4.1-3 where Psyche calls on Juno to intercede on her behalf. She addresses the goddess in her various regional guises and powers, naming Samos, Carthage and Argos as places where she is most venerated (the same three named by Virgil). And she begins by calling upon her as magni Iouis germana et coniuga. On Carthaginian features of Apuleius's novel with specific attention to the wrath of Juno, see Graverini (2014, 119-23). 
(unde), it is no wonder that you keep such huge wrath held back beneath your chest. For we know that each person is roused to anger according to the quality of his birth or family line (pro generis qualitate). For nobles, even if they seem to be indulgent and to forgive in the present, nonetheless they keep their wrath in reserve for a later time. This is what he (Jupiter) seems to charge against Juno here. For although she claims to surrender, she has pursued whatever would do serious harm to the Trojans. Thus Homer has Calchas say of Agamemnon: "the anger of kings is such that even if they seem to be lenient for now, they are holding back the goads of wrath for another time."

Of particular interest here is the 'matter of fact' way that Servius makes his claim: scimus 'we know,' as if to say 'it's perfectly self-evident,' that the ability to suppress anger, and to keep it on a slow boil until such time as you choose to let it out, is directly proportional to the quality of one's birth (pro generis qualitate). The higher up the scale of nobility, the more you have it, and the farther down you slide on that same scale, the less of it you have, until such point as you have none at all. And to prove his point, he trots out a passage gleaned from the pages of Homer, telling us that kings know how to store up their anger, and to keep it in check, waiting until the time is right. It is a particular gift that kings have, because they are nobly born, and capable of such self-control. The quote comes from lines 81-3 of Iliad book one, where Calchas warns Achilles that some king (the as yet un-named Agamemnon) will become very angry if he proceeds to divulge the cause of the plague. He worries aloud that even if this king were to pretend that all is well for the moment, he will keep his anger pent up, and unleash it against him at a later time. Calchas hints to Achilles that he is about to provoke a powerful man, who is bound to seek retribution, and that claim is generalized by Servius into a lesson about how kings behave, and the superior qualities of the souls they possess. As strained as this take on Calchas's words may seem, Servius's comments 
shed a sliver of light on how Homer was taken up with in the schools of the late fourth and early fifth centuries CE; how his poems were used not only for the grammatical and literary instruction of young Romans, but for their moral instruction as well, i.e. Homer understood in Roman terms, put to use for the reproduction of Roman cultural values, and for telling stories to Romans about themselves. In this case, the lesson spun from Virgil, by way of Homer, concerns how young Roman nobles should understand what they are made of inside; how their emotional selves (their souls) were, in fact, superior to those of most others in the world; how, in essence, they were born to rule, because they had something that most people did not: a noble family line, and the complete inner self that goes with it.

To make his point, Servius refers his readers to a scene that all would have recalled from their earliest days as students of Greek poetry. Pored over in the schools of the grammarians, no other book was more basic to the education of Greeks in the east, and learners of Greek in the west, than book one of the Iliad. ${ }^{12}$ Servius's comments let us see how the anger of Achilles and Agamemnon was taken up with in the schools of Rome, turned to the cause of teaching lessons about self-control; lessons about how persons of a certain higher 'kind' behave, and how they differ from others in the fundamental makeup of their inner selves. Persons who are well born, says the stickwielding grammarian, know how to assert control over their emotional demons in ways that ignoble people do not. There are many memorable (and therefore easily cited) moments in the Odyssey and the Iliad where one might pause to teach this lesson: Odysseus resisting the urge to kill the Cyclops in book 9 , for example, or his restraining himself from killing the maids as

12 On the centrality of Homer in the enkyklios paideia of the Greeks, and within Greco-Roman education more generally, see Morgan (1998, 67-78) ('Homer is the quintessential Greek author, associated with hellenism and pan-hellenism as far back as we can trace,' p. 75). 
they slink off to sleep with the suitors at the beginning of book 20. But to explain the 'stowing' of Juno's illimitable anger at the end of the Aeneid, Servius takes his readers back to the fight that erupted between Agamemnon and Achilles in Iliad book 1 , which is likely to have been their first encounter with epic rage as a narrative theme parlayed into lessons about themselves. That men of noble birth have superior self-control is hard to make out as the best and/or most obvious construal of Calchas's assertion about kings holding their rage in reserve. But it is easy to see why Servius should make reference to book one of Iliad in order to spin this lesson, because the idea is famously dramatized in lines 188-218 of Iliad book one, where Achilles draws his sword in order to kill Agamemnon, but then Athena arrives on the scene to stay his hand. Taking control of his rage, as logos to menos (reason asserting control over rage), she grabs him from behind by the hair, and he spins around, quite shocked to see her there. Athena then commences to reason with him, and to strategize: 'I have come from heaven to restrain your fury,' she

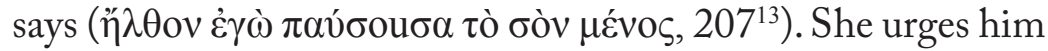
to let Agamemnon have his way for the moment, saying that the better plan is to step away and let Agamemnon suffer the disastrous consequences of his folly. Achilles sees the sense of this. He swallows his rage, and for the next 15 books he keeps his sword peacefully stowed away. This is both the initial, and most famous, instance of rage suppression in the Iliad. I will return to it, as a point of comparison, in dealing with the rage suppression of the Aeneid's first simile.

But first, I would like to consider another famous moment of violent emotions brought to heel in book two of the Iliad, a scene that is, in many obvious ways, parallel to the suppression of

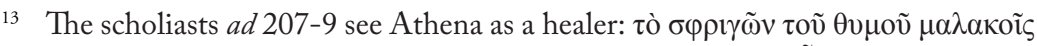

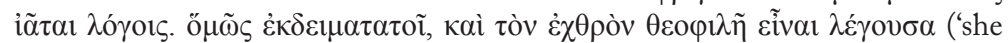
heals the swelling of his passion with soothing words. At the same time she thoroughly frightens him, saying that his enemy is also dear to the gods'). 
Achilles'wrath in book one. In fact, as Denis Feeney has so well shown, it is this latter scene that Virgil engages with in firing up, then sedating the storm that scatters the Trojan ships in Aeneid book one. ${ }^{14}$ At the beginning of Iliad book 2, sent a false dream by Zeus, Agamemnon takes it into his head to announce to the gathered armies of the Greeks that they are through with fighting; that it is time to go home. Thinking that his announcement would shame them, and work them into a fury for finishing the job, Agamemnon actually causes the gathered throng of soldiers to break out in a rush towards the ships, only too glad to give up the nine-year siege and sail for home. Chaos ensues. Odysseus sees that Agamemnon has done something reckless, and that he has lost control, so (sent by Athena who, as in book one, has been sent by Hera) he grabs the king's studded scepter and enters into the fray. His authority and verbal cleverness are required. Every time he meets a person of rank, Homer says, someone in

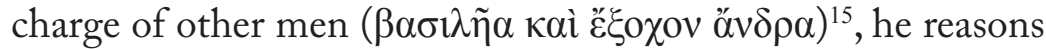
with him using gentle words ( $\dot{\alpha} \gamma \alpha v o i \tilde{\varsigma} \varepsilon \dot{\varepsilon} \varepsilon \dot{\varepsilon} \varepsilon \sigma \mathrm{v}){ }^{16}$, as a friend, and he calls upon him to understand Agamemnon's real purpose, and to honor Zeus's will and continue the fight by taking control of his men. But, Homer says, whenever he came across a common

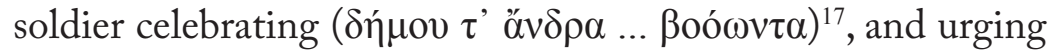
retreat, he beat him with the king's scepter and berated him as a fool, a deserter and a coward. The most famous loud-mouth among these common soldiers is Thersites, whose ugliness (he is a bald, hunch-backed, bandy-legged, and club-footed weakling) is the outward expression of his internal state. When Odysseus catches Thersites scoffing at a king he berates him as a dog. He threatens to strip him of his clothes, and whip him howling back to the ships. Then he cracks the scepter across his back, raising

\footnotetext{
14 Feeney (2014).

15 Hom. Il. 2.188.

16 Hom., Il. 2.189.

17 Hom. Il. 2.198.
} 
a bloody welt between his shoulder blades and bringing tears to his eyes. Thersites is chastened. He obediently cowers like the dog he has been called out as, and says not another word. The other common soldiers see this and, respecting the kingly scepter in Odysseus's hand, they join in berating Thersites. Then they come back into their ranks, become silent, and stand at attention. Order is restored.

In both the cases that I am inviting you to consider, that of Achilles near the beginning of book one, and that of Thersites near the beginning of book two, powerful emotions of anger and pent up passion burst forth from characters who are momentarily swept up by a loss of emotional control. Their outbursts are then swiftly checked by forces that come from outside the characters themselves: for Achilles, a godlike king, his rationality, the ability to strategize and to control the powerful impulse that urges him to kill Agamemnon on the spot, comes in the form of a goddess whom he alone can see, and who is uniquely concerned with his achieving the unparalleled honor that he covets and demands as 'the best of the Achaeans.'For Thersites, a low-born, recalcitrant loud-mouth, 'listening to reason' has nothing to do with reason, or with strategizing, and everything to do with the fear of pain and public shame. Reasoning, Homer indicates, is reserved for leaders. Odysseus addresses himself differently to them. Given who he is, Thersites (it is understood) is incapable of reason. His impulse control comes from the outside not in the form of a goddess, but a studded stick that Odysseus uses to inflict pain and public shame by planting it in his back. ${ }^{18}$ Thus, built

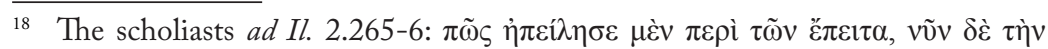

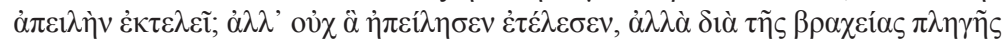

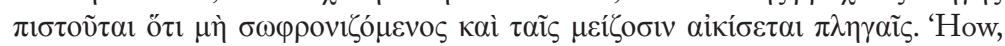
on the one hand, did [Odysseus] make threats about these things before-- and, on the other hand, is he delivering on those threats now? But he has not carried through with what he threatened. Rather, through this one passing blow, he confirms that one who is recalcitrant and out of control will be tortured with blows by better men.' 
into these two stories we have two very different, and yet clearly related, ways of thinking about human agency, the assertion of control over the emotions, and the human self. Achilles, on the one hand, is psychologically completed by having the goddess of reason herself take an interest in him and intrude upon his thoughts: Homer's gods are concerned with nobles who, it is understood, are descended from them, and they maintain an actively favoring 'presence' in their lives. As for ignobles and nobodies in the Homeric world-- and much of what I say here can be taken to apply to the perceived psychological makeup of women, slaves, children, and foreigners as well - they are psychologically 'completed' not by anything in themselves, not by the capacity for reason that Athena represents, but by someone who is himself psychologically complete in himself ( $a$ father, an elder male, a king); persons complete and in control of themselves, persons gifted with reason in a way that they can never be. It is taken for granted that inferior persons, such as Thersites, are naturally incapable of self-control. Their psyches are incomplete. They require a male 'head' outside of themselves to make them complete by asserting control over not only their bodies and its physical needs, but their emotional inner workings as well, by putting strict limits on those emotions, training them (insofar as they can be trained), and teaching them to obey. The ones gifted with self-control are needed to control others, persons of lower 'kinds.'The main expositor of this way of thinking in antiquity is Aristotle, but his categorizations of humans according to their kinds in the first book of the Politics take up with ideological 'givens' that had been around for as long as the Greeks had given thought to the question of why some men rule, and others obey. Though it is as yet under-rationalized as political theory, the basic thinking behind Aristotle's categorizations can be made out in the assumptions and doings of Homer's heroes.

I want to turn now to book one of the Aeneid, to see how some of these same ideas about anger and its suppression pro generis qualitate are taken up with by Virgil in the famous 'pious 
statesman' simile that is the first extended simile of the poem. In a recent study of the epic's initial simile, Damien Nelis has argued that the violent winds and surging seas that are whipped up by Aeolus literalize an analogy common in Lucretius: that of the 'storm-tossed' soul. The storm is a soul image, in other words, 'a symbol of Juno's impassioned state of mind. ${ }^{19}$ As such, the angry seas that threaten to annihilate the Trojans do not just arise from Juno's anger (as a mere narrative fact), they represent the enraged state of her soul. The storm is thus both fact and figurative symbol at the same time (something that $V$ irgil is very fond of $).{ }^{20}$ In a separate article on first similes in epic, Denis Feeney has shown how Virgil constructs his programmatic first simile out of initial similes and simile sequences in earlier epic poems, thereby availing himself of similes that were already heavily encoded and programmatic in function, each serving as a uniquely constructed icon of the relationship between human beings and the natural world. ${ }^{21}$ With Virgil's 'orator in the storm' simile, Feeney shows, the main points of comparison in earlier epic are with initial similes and simile sequences in Homer's Iliad and Lucretius' de Rerum Natura, where chaotic storms are used to introduce, in picture form, the political and natural/elemental workings of their respective worlds. A 'storm' of sedition put down by kingly authority in Homer (the second simile of the Iliad that describes the riot of book two) becomes,

19 Nelis (2015,156); cf. Sen. Ep. 14.7: itaque sapiens numquam potentium iras provocabit, immo [nec] declinabit, non aliter quam in navigando procellam.

20 For example, the storm-tossed ship that Aeneas sails in is easily read as a 'ship of state,' especially given the political tenor of the simile that describes the storm. The ship is obviously susceptible to being treated as an allegory in that sense. And yet it is a 'ship of state' in a more literal sense as well: should this ship sink and take Aeneas to a watery grave, it will take the (future) Roman state down with it. It is thus a symbol of a state in peril, and an actual state in peril (Rome), at the same time. Further on the gods in Virgil as, all at once, symbols/tropes and epic characters/gods, see Feeney (1991) 134-137 on Virgil's 'stereoscopic focus' on the gods in the Aeneid.

21 Feeney $(2014,189)$. 
in Lucretius, a way of imagining Nature's powers as blindly destructive and not subject to human authority.

It is my intention in the remainder of this paper to make a tertium quid out of what these two recent papers have argued by calling attention to certain features of the image's internal figuration that actively invite us connect 'state' to 'soul' in Virgil's first simile, and to regard them as inseparable, each its own metaphor for the other. In so doing, I hope also to show just how radically Virgil has recalibrated the workings of the soul to make it receivable as an expression of Roman ideas about the Roman self, and the Roman state, respectively. Because specific figurative details are crucial to this argument, I quote the simile in full:

Sic ait, et dicto citius tumida aequora placat, collectasque fugat nubes, solemque reducit. Cymothoe simul et Triton adnixus acuto detrudunt navis scopulo; levat ipse tridenti; et vastas aperit syrtis, et temperat aequor, atque rotis summas levibus perlabitur undas. Ac veluti magno in populo cum saepe coorta est seditio, saevitque animis ignobile volgus, iamque faces et saxa volant - furor arma ministrat; tum, pietate gravem ac meritis si forte virum quem conspexere, silent, arrectisque auribus adstant; ille regit dictis animos, et pectora mulcet, sic cunctus pelagi cecidit fragor, aequora postquam prospiciens genitor caeloque invectus aperto flectit equos, curruque volans dat lora secundo. ${ }^{22}$

Neptune says these things, and before his final word is spoken he soothes the swollen waves, sends the gathered clouds flying and brings back the sun ... he lays the sea flat and glides over the surface of the waves on light wheels. Just as, often, when a riot breaks out in a huge crowd, and the low rabble are howling in their spirits, and soon torches and stones are sent flying - their rage

\footnotetext{
$22 \quad$ Virg. A. 1.142-56.
} 
serving them with weapons - then, if they happen to catch sight of some man who is heavy/burdened with piety and accolades well earned, they are silent and stand still, with their ears pricked up to listen. He steers their passions with his words, and he soothes their emotions (lit. 'pets their chests'). Just so the crashing of the sea subsides after the Father, looking out over the waters and riding in the open sky, turns his horses aside and gives them free rein as he flies trailing in his chariot.

Homer compares a political riot to a storm. Virgil compares a storm to a political riot. So much is obvious. But within the simile Virgil develops a further metaphorical conceit comparing the rampaging winds to unruly horses calmed and steered by an expert driver. The 'horsey-ness' of the simile has been noted by several scholars, ${ }^{23}$ and I have nothing to add to their observations here: Aeolus controls the winds by 'knowing how to hold tight and give slack to the reins' (premere et laxas sciret dare ... habenas, 1.63); the winds go racing out of their carcer (a prison, that is also the starting gate of a horse race; in fact it is one that gets poked in the side by a goad); they are steered and petted by the man who arrives to calm them (regit, mulcet), and they even prick up their ears as horses do (Servius notes that there is a an animal metaphor here, a translatio a mutis animalibus, quibus aures mobiles sunt' a metaphor from the realm of dumb animals that have mobile ears'). Then, to contrast and carry through with the imagery of wild horses restrained by an expert horseman, Virgil paints a picture of Neptune, the horseman/statesman's counterpart, riding away once the storm has been stilled. Exerting effortless control over his horses, Neptune loosens the reins and lets them fly ahead as they pull him into an open sky. ${ }^{24}$ The language is that of heavenly flight

23 On the equine imagery of Aeolus's winds, with relevant background in previous scholarship, see Feeney $(2014,215)$.

24 Wilhelm $(1982,217)$ : 'In the Aeneid mastery and control of the chariot is an effective political metaphor: in the first simile of the Aeneid (1.148-156), the sea 
(caeloque invectus aperto ... volans), as if these were the winged horses of Helios rather than Neptune's hippocamps scudding along on top of the waves.

The devil, I suggest, is in the details: the chastened rioters' pricked up ears, with the soothing stroke of the mystery leader's words, set alongside the imagery of Neptune as a skilled chariot driver, steering horses that are the picture of restraint. If, as Nelis has argued, there is soul symbolism built into this simile, I suggest that the details add up to the basic figurative conceits of the soul imagery Plato's Phaedrus. There, famously, the ideal human soul was likened by the philosopher to a chariot hitched to two horses, steered by a driver skilled at checking the passions of a frenzied horse. One recalls that Plato, in fact, draws two pictures of chariot souls in the Phaedrus that he sets in contrast: the souls of the gods, comprised of drivers pulled by white winged horses, perfectly trained, that soar effortlessly upwards into the heavens, to the higher places where they belong; ${ }^{25}$ contrasting human souls that stay low to the ground, because they are heavy, erratic and prone to going off course, pulled along by horses of opposite types: one white, well born, and attuned to the wishes of the driver, the other dark, unsightly, ignoble, and erratic. ${ }^{26}$ Though not entirely un-trainable, this ignoble horse has to be whipped and scolded in order to stay on course and keep an even pace with its better half. He is the symbol of

is quieted and the winds forced to retreat by Neptune who drives a currus like a wise statesman imposing Roman order on the mob threatening destruction.' Wilhelm goes on to mention the charioteer/soul allegory of Phaedrus 246A-247A within a longer list of Greek sources where crazed and ferocious mental states are compared to chariots racing out of control, but he does not attach any of these soul potentials to Virgil's first simile. In commenting on the chariot race simile of Virgil Georg. 1. 509-514, Schindler (2000) 207 cites all the most important 'soul' and 'state' uses of the metaphor prior to Virgil (including that of Plato's Phaedrus) but makes no attempt to explore the possibility of their full integration.

25 Pl. Ph. 246e-247c.

26 P1. Ph. 253d-e. 
unchecked impulse and base desire. In essence, he is a Thersites in need of a stick, wielded by a rational power outside of himself. According to the political rendering of the tripartite soul idea in Plato's Republic, he is the impulsive and erratic demos of the democratic stae.

We see similar things going on in Virgil's first simile. Or so I maintain. The storm that both symbolizes, and erupts from, the outraged state of Juno's soul, is likened to a city torn apart by civic strife, its violent masses of low born men (ignobile volgus) figured as so many ill-bred horses careening wildly out of control, then brought into line by a seasoned statesman who knows how to work the reins. Within a larger Platonizing reading of Homer's heroes, the second century CE rhetorician/ philosopher, Maximus of Tyre, found in Homer's Thersites not just a despicable character in need of a thrashing, but 'a perfect allegory of an insubordinate citizenry. ${ }^{27} \mathrm{I}$ suspect that it is from some early version of this allegorization that Virgil fashions his ignobile volgus, by concretizing the symbolic potentials that others had worked out from Homer's Thersites. But in Virgil's reworking of the 'political storm' of Homer's second book, there are no beatings, and no beratings. The statesman who calms the riot is an Odysseus ('a good man and a meticulous leader ${ }^{28}$ ) without a regal stick. The simile has built into it a fantasy of authority that speaks to the desires of a people worn out by civil strife. Virgil's Romans knew all about buildings being torched and riotous gangs marauding through the streets, killing as they went. The scenario Virgil paints in the simile was all much too real to a Roman audience of the twenties BCE. Such was the reality that all Romans knew from their own lives in the

\footnotetext{
27 Maximus Oration 26.5. Further on Maximus of Tyre's allegorization of Thersites, see Kim (2010, 11), and Hunter (2012, 59-60). On the proliferation of political and 'origins of satire' readings of the Thersites episode in imperial Greek sources, see Hunter (2009, 86-9).

28 Maximus of Tyre Oration 26.5, referring to Odysseus as a proto-Socrates.
} 
previous thirty years. For most of this period Rome was rocked by periodic upheavals of partisan violence. It had become a city of burnt out ruins. But Virgil's opening simile paints a wondrous scenario wherein all of that violence instantly disappears. It lets Romans think: 'what would it be like to have some man, a living monument of traditional values, come along who could make all that go away, just by stepping out onto the scene?' That is what the simile, loaded with resonances to Homer, Hesiod, Lucretius, Greek political and moral philosophy, and recent Roman history, has us imagine: a man whose auctoritas is just that overwhelming - legible by all, immediately recognized and respected, and not subject to confusion or deleterious interpretation. ${ }^{29}$ What a wonderful fantasy!

Many answers to the mystery man's identity have been proposed. ${ }^{30}$ But what I find so fascinating about the soul/state figure as Virgil (re)deploys it here is less the identity of the man, which I take to be deliberately irresolvable (with its irresolvability being the point ${ }^{31}$ ), but that his authority should be said rest not in his superior reasoning capacity (his ratio or logos) but in

29 On the simile's various models and intertextual engagements, see Beck (2014, 69-75).

30 The man most commonly proposed is Augustus, who was favored by Neptune in his defeat of Sextus Pompey. See Galinsky (1996, 21-3). There is no doubt that Augustus is in some sense 'here' as bait for the taking. But the simile invites multiple identifications, and can be entered into from various political angles, such that a reader of one political persuasion will end up with Augustus, while another will end up with Poppilius Laenas, or Menenius Agrippa, or someone else who fits the bill. One sees, for example, that in describing Lucan setting off to compose his Pharsalia at Silvae 2.7.68-9, Statius makes reference to Virgil's first simile in a way that has the younger Cato in the role of the mystery man (= a way of reading Lucan for the way that Lucan read the Aeneid): Libertate gravem pia Catonem / et gratum popularitate Magnum ('You will sing of) Cato, heavy in pious commitment to freedom, and Pompey, the favorite of the masses.'

31 Feeney $(2014,214)$ : 'It is in the end misguided to press too hard for an identification with one particular individual or episode, given the generalizing and paradigmatic nature of the simile.' 
his 'piety' (pietas), a concept Roman to the core, and virtually without equivalent in Greek. For as Greek as this soul picture is in its origin and basic design, it has something new about it that it never had, nor could have had, in any Greek source. In fact, it is this precise word, pietas, that the Romans were wont to trot out when touting their superiority over the Greeks, and rationalizing their right to rule over them. This is what both Polybius and Dionysius of Halicarnassus are getting at when they attempt to describe to their Greek readers the special religious 'something' that Romans had that they themselves did not, and that gave the Romans superior skills of statesmanship, and success at running a world empire. At Histories VI.56.614 , for example, Polybius famously asserts that 'the respect in which the Roman constitution is most markedly superior is in

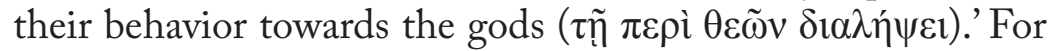
his Greek readers, this is a stunning claim. He goes on to say that it is their 'superstitiousness' that keeps the Roman state

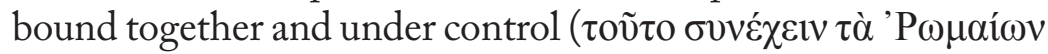

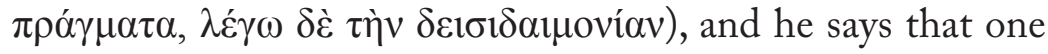
cannot overstate just how completely this cautious disposition towards unseen powers dominates their public and private lives. He then adds: 'For many would find this astonishing. To me at least it seems clear that all this has been done for the sake of the

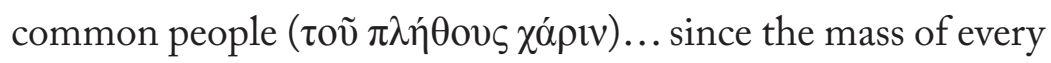
people is fickle and full of lawless desires, irrational anger and violent impulses, it is essential that they should be restrained by invisible terrors and other suchlike melodramas.' All silly stuff, in other words, dismissed as the $\delta \varepsilon 1 \sigma 1 \delta \alpha \mu$ oví $\alpha$ of the masses. And yet this 'fear of spooks' is unlike anything known to the Greeks, because the Romans are so preternaturally absorbed by it as a people, constantly performing their commitment to getting things right between themselves and unseen tutelary powers in every aspect of their lives. It is this mystery stuff that, Polybius claims, binds the Roman state together, and commits all Romans to their collective cause, allowing them to run an 
empire for the long term. Much else that Polybius says about the cultural factors behind Roman imperial success in book six of his Histories -- their patriotism, for example, their respect for ancestors, the melodramatic nature of their aristocratic funerals, and so on-- any Roman might look at and say, 'yes, what you're noticing about us is our pietas. Why don't you just say that?' And of course he cannot. There is no equivalent cultural disposition among the Greeks, and thus no handy Greek word to express it. Polybius might have tried using the term eusebeia, which is the most common Greek translation of Latin pietas, but because eusebeia is much too suggestive of the right and measured attachment to the gods that the Greeks themselves thought they knew best how to maintain, its use in describing something that was as privately and personally and culturally all-encompassing as pietas was to the Romans is severely limited.

The idea that pietas keeps the Roman masses in check, then, is not new to Virgil. What is new is his elaboration of that idea in picture form, in a simile that shows the workings of auctoritas within the Roman state on its surface (as its obvious 'tenor' or point of comparison), even as it develops a second metaphor of the workings of the soul by calling to mind the imagery of Plato's Phaedrus, along with the state/soul analogy of the Republic. ${ }^{32}$ The conceptual prerequisites for producing

32 Cicero develops a charioteer 'state/soul' metaphor at de Republica 2.6768. There, in concluding the political conversation of day two, he has Scipio and Laelius reminisce about their days together in Africa: (Scipio) '<quem> iamdudum quaero et ad quem cupio pervenire.' (Laelius) 'prudentem fortasse quaeris?' tum ille (Scipio): 'istum ipsum' (Laelius) 'est tibi ex eis ipsis qui adsunt bella copia, velut a te ipso ordiare.' tum Scipio: 'atque utinam ex omni senatu pro rata parte esset! sed tamen est ille prudens, qui, ut saepe in Africa vidimus, immani et vastae insidens beluae, coercet et regit [beluam] quocumque volt et levi admonitu aut tactu inflectit illam feram.' (Laelius) 'novi et tibi cum essem legatus saepe vidi.' (Scipio) 'ergo ille Indus aut Poenus unam coercet beluam, et eam docilem et humanis moribus adsuetam; at vero ea quae latet in animis hominum quaeque pars animi mens vocatur, non unam aut facilem ad subigendum frenat et domat <beluam>, si quando id efficit, quod perraro potest. namque et illa tenenda est ferox.' 
such a re-elaboration (that is, the pre-existing propensities of thought that would make such an image conceivable as such) were already there to be tapped into and played upon, as pre-existing langue to the parole of the simile's specific articulation. For Virgil's Roman audience, pietas is not just a disposition that regulates behavior in the public sphere, i.e. a dispositional affect of the group that influences the emotional states of individuals from the top down. Rather, it is both first and foremost a guiding force that steers good Romans from inside themselves, committing them to the causes of family, gods, and the state. It is an emotional disposition that checks and steers individuals from the inside, thus working from the bottom up. ${ }^{33}$ And thus,

'(It's him) I have been seeking out for some time, and whom I'm anxious to reach. (L) 'Perchance you are seeking a man endowed with wisdom/foresight?' Then he: (S) 'That's the one!' (L) 'You have a lovely abundance of them among men right here. You can start with yourself!' Then Scipio (S) 'If only that were the settled opinion of the entire Senate! However, there is that wise man whom I would often see in Africa, sitting atop a giant and monstrous beast. He checks and steers the beast wherever he wants, and with the slightest utterance and touch he turns the beast.' (L) 'Yes, I know the man. I saw him lots of times when I was with you as a legate.' (S) 'And so it is that a man from India or Carthage controls a monster that is a single entity, both docile and accustomed to the ways of humans. But what hides in the souls of men, and the part of the animus that we call 'mind,' reins in and tames a beast that is not singular or easily mastered. It's a rare thing when it happens, for it's a wild thing to hold onto.'

Section 68, directly following, is highly fragmentary, but clearly invokes the metaphor of the charioteer statesman (ut auriga indoctus e curru trabitur, opteritur, laniatur, eliditur 'as an ignorant charioteer is dragged from his car, trampled, torn apart, crushed') within a larger discussion comparing unruly passions to violent beasts that must be held in check.

Commenting on the fragments of sections $67-68$, Ferrary $(1995,62)$ concludes: 'The image of the mahout illustrates the spirit of reason within the soul of the prudens, but implicitly also the role of the prudens or rector within the city. As in Plato's Republic, the parts of the city are analogous to the parts of the soul.'

33 This is a very big proposition that requires much more space than I can devote to it here. If only to suggest that such ideas about human agency were at least 'available' to Virgil and his readers, I offer two small textual illustrations, one from an author that Virgil is sure to have read, and a second from Virgil himself. The first is fragment 2 Courtney (= Priscian apud G.L. II, p. 419 Keil) of Livius 
what Virgil puts on display in his image of a soul/state regulated by pietas is a very different articulation of what the human soul is, unlike anything seen in the Greek sources from which Virgil gathers the simile: not mind over body, but a moral conscience structured by, and steeped in, tradition. Piety over body. In fact, what we have here is not the human soul generally construed, but an idealized Roman soul, one dominated in its decision-making and emotional comportment not by its capacity for logos, for calculation and rational dialectic, but by an ingrained reverence towards tradition and towards the reverential ways of

Andronicus' Latin translation of Homer Od. 20.19-20. There, in fighting down the urge to kill the wayward maids, Odysseus reminds his heart of the rage he felt 'on that day when the Cyclops, irrepressible in his menos, consumed your

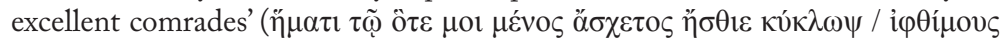

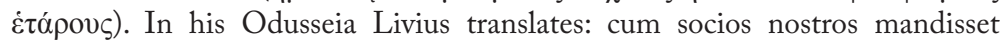
impius Cyclops. The passage is thought to be a very loose translation of the

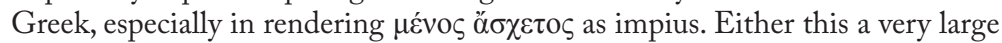
'leap' made by Livius, or (to introduce an idea that is as yet unconsidered) he is working with a different sense of what piety is and how it operates, i.e. as an internal check on 'rage' that the Cyclops, being a Cyclops, does not have. My Yale colleague, Egbert Bakker, notes per litteras that the LSJ entry for ó $\sigma \chi \varepsilon \tau$ is in need of revision: 'The point is that ö $\sigma \chi \varepsilon \tau 0 \varsigma$ is often combined with $\pi \varepsilon \dot{v} v 0 \varsigma$

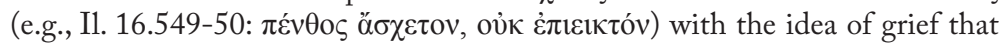
cannot be repressed (and is "unyielding"). But this "passive" meaning does not translate to cases where the adjective is applied to persons. When Antinoös

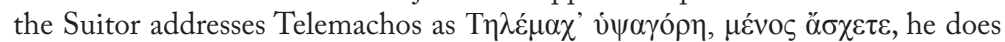
not mean that Tel. is "irresistible in his menos", but someone impetuous, who cannot repress his (own) menos (note also that $\mu \varepsilon \dot{v} v \varsigma$ ó $\sigma \chi \varepsilon \tau \varepsilon$ occupies the

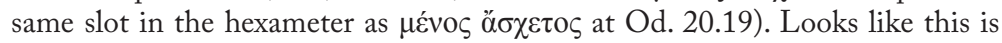
a typical Odyssey usage. At 3.104 it could go either way.' Similarly, at Aeneid 4.393-96, it is Aeneas's piety that keeps his passions (pity and love) in check: At pius Aeneas, quamquam lenire dolentem / solando cupit et dictis avertere curas, / multa gemens magnoque animum labefactus amore / iussa tamen divum exsequitur classemque revisit. Cf. Aen. 7.21 where it is again their piety that keeps the Trojans from being lured aside by Circe's seductive song. The several translational leaps taken by Livius in his translation of Homer Od.20.19-20 are sorted through by Traina (1960), who argues that it is in fact a translation of Od. 9.296-7. This argument poses its own set of problems, but has been lent support by Courtney $(1993,45)$. 
one's ancestors. It is, in end, a way of thinking about the inner workings of mind over body that is also a theory of empire.

\section{Works Cited}

Beck, D. 2014. 'The First Simile of the Aeneid,' Vergilius 60: 67-83.

Courtney, E. 1993. The Fragmentary Latin Poets. Oxford.

Feeney, D.C. 1984. 'The Reconciliations of Juno,' Classical Quarterly 34: 179-184.

Oxford.

1991. The Gods in Epic: Poets and Critics of the Classical Tradition.

2007. Caesar's Calendar: Ancient Time and the Beginnings of History. Berkeley.

2014. 'First Similes in Epic,' Transaction of the American Philological Association 144: 189-228.

MA.

2015. Beyond Greek: the Beginnings of Latin Literature. Cambridge,

Ferrary,J-L. 1995. 'Statesman and law in Cicero's political philosophy.'In: A Laks and M. Schofield, eds. Justice and Generosity: Studies in Hellenistic Social and Political Philosophy. Cambridge: 48-73.

Galinksy, K. 1996. Augustan Culture: an Introduction. Princeton.

Graverini, L. 2014. 'The Negotiation of Provincial Identity through Literature: Apuleius and Vergil.' In: B. Lee, E. Finkelpearl, and L. Graverini, eds. Apuleius and Africa. New York and London: 112-128.

Harrison, S. J. 1988. 'Vergil on Kingship: the First Simile of the Aeneid,' PCPS 34: 55-59.

Hunter, R. 2009. Critical Moments in Classical Literature. Cambridge.

. 2012. Plato and the Traditions of Ancient Literature. Cambridge.

Kim, L. 2010. Homer Between History and Fiction in Imperial Greek Literature. Cambridge.

Lintott, 1980. 'What was the "imperium Romanum"?' Greece and Rome 28: 53-67.

MacMullen, R. 2000. Romanization in the Time of Augustus. New Haven. 
Morgan, T. 1998. Literate Education in the Hellenistic and Roman Worlds. Cambridge.

Nelis, D. 2015. 'Juno, sea-storm and emotion in Virgil, Aeneid 1.1-156: Homeric and Epicurean contexts.' In: D. Cairns and L. Fulkerson, eds. Emotions Between Greece and Rome. London: 149-162.

Reed, J. 2007. Virgil's Gaze: Nation and Poetry in the Aeneid. Princeton. Schindler, Claudia 2000. Untersuchungen zu den Gleichnissen im römischen Lehrgedicht: Lucrez, Vergil, Manilius. Göttingen.

Scullard, H. H. 1969. A History of the Roman World, 753 to 146 BC. London.

Selden, D. 2014. 'Apuleius and Afroasiatic Poetics.' In: B. Lee, E. Finkelpearl, and L. Graverini, eds. Apuleius and Africa. New York and London: 205-270.

Sherwin-White, A.N. 1973. The Roman Citizenship. Oxford.

Shi, V. and Morgan, L. 2015. 'A Tale of Two Carthages: History and Allusive Topography in Virgil's Libyan Harbor (Aen. 1.159-69),' TAPA 145: 107-133.

Skutsch, O. 1985. The Annals of Quintus Ennius. Oxford.

Tarrant, R. 2012. Virgil Aeneid XII. Cambridge.

Thomas, E. 2007. Monumentality and the Roman Empire: Architecture in the Antonine Age. Oxford.

Traina, A. 1960. 'Note esegetiche I: Il pasto di Ciclope e gli esametri pseudoliviani,' Maia 12: 220-224.

Wilhelm, R 1982. 'The Plough-Chariot: Symbol of Order in the Georgics,' CJ 77: 213-230.

Woolf, G. 1998. Becoming Roman: the Origins of Provincial Civilization in Gaul. Cambridge. 